\title{
The indigenisation of eco-theology: The case of the Lamba people of the Copperbelt in Zambia
}

\begin{tabular}{|c|c|}
\hline \multicolumn{2}{|c|}{$\begin{array}{l}\text { Authors: } \\
\text { Lackson Chibuye }^{1} \text { (D) } \\
\text { Johan Buitendag }^{1} \text { (D) }\end{array}$} \\
\hline \multicolumn{2}{|c|}{$\begin{array}{l}\text { Affiliations: } \\
{ }^{1} \text { Department of Systemat } \\
\text { and Historical Theology, } \\
\text { Faculty of Theology and } \\
\text { Religion, University of } \\
\text { Pretoria, Pretoria, } \\
\text { South Africa }\end{array}$} \\
\hline \multicolumn{2}{|c|}{$\begin{array}{l}\text { Research Project Registration: } \\
\text { Project Leader: J. Buitendag } \\
\text { Project Number: } 02402343\end{array}$} \\
\hline \multicolumn{2}{|c|}{$\begin{array}{l}\text { Description: } \\
\text { This research is part of th } \\
\text { project, 'Theology and } \\
\text { Nature', directed by Prof. } \\
\text { Dr Johan Buitendag, } \\
\text { Department of Systemati } \\
\text { and Historical Theology, } \\
\text { Faculty of Theology and } \\
\text { Religion, University of } \\
\text { Pretoria. }\end{array}$} \\
\hline \multicolumn{2}{|c|}{$\begin{array}{l}\text { Corresponding author: } \\
\text { Johan Buitendag, } \\
\text { 1jbuiten@gmail.com }\end{array}$} \\
\hline \multicolumn{2}{|c|}{$\begin{array}{l}\text { Dates: } \\
\text { Received: } 29 \text { Apr. } 2020 \\
\text { Accepted: } 04 \text { Aug. } 2020 \\
\text { Published: } 12 \text { Oct. } 2020\end{array}$} \\
\hline \multicolumn{2}{|c|}{$\begin{array}{l}\text { How to cite this article: } \\
\text { Chibuye, L. \& Buitendag, J., } \\
\text { 2020, 'The indigenisation of } \\
\text { eco-theology: The case of the } \\
\text { Lamba people of the } \\
\text { Copperbelt in Zambia', HTS } \\
\text { Teologiese Studies/ } \\
\text { Theological Studies 76(1), } \\
\text { a6067. https://doi. } \\
\text { org/10.4102/hts.v76i1.6067 }\end{array}$} \\
\hline \multicolumn{2}{|c|}{$\begin{array}{l}\text { Copyright: } \\
\text { (C) 2020. The Authors. } \\
\text { Licensee: AOSIS. This wor } \\
\text { is licensed under the } \\
\text { Creative Commons } \\
\text { Attribution License. }\end{array}$} \\
\hline \multicolumn{2}{|l|}{ Read online: } \\
\hline 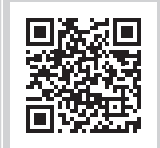 & $\begin{array}{l}\text { Scan this QR } \\
\text { code with your } \\
\text { smart phone or } \\
\text { mobile device } \\
\text { to read online. }\end{array}$ \\
\hline
\end{tabular}

This article shows how eco-theology could and should be indigenised in an African context using the Copperbelt in Zambia as a case study. The ecological crisis worldwide has given rise to the call for everyone to work together to start caring about our natural environment. In theology, the response to this call received the name eco-theology. By means of a literature review, ethnographic information and governmental legislation, the article tries to illustrate how eco-theology could and should be indigenised in an African context using the Copperbelt in Zambia as a case study. This article makes an attempt to contribute to the needed ecological renewal by reinterpreting two traditions that inform thinking on the Copperbelt: Christianity and African traditional religion. The supernatural belief of the Lamba people is no longer embodied in this creation, and it is not too late for the people to form any indigenous environmental protection movement to protect the sacredness of mother Earth from further contamination and exploitation by strengthening, maintaining and respecting the traditional teachings and the cultural laws. Obedience to God's command to tend creation is a quest for continued creation by humans, so that value is added to what is already in existence. This is embodied making the place we live in more beautiful, appealing and peaceful. Fruitfulness with sustainability becomes core values for interdependence and earth keeping.

Contribution: We wish to address the ecological situation of the mining industry in Zambia from a theological perspective by assessing the impact of the copper mining and processing industry on humans, their environment and nature and by showing how the traditions of African traditional religion (ATR) thought can be transformed into tools to oppose this ecological disaster.

Keywords: Eco-theology; Copperbelt; Ecology; Eco-hermeneutics; Dominium command; Industrial exploitation; Earth Charter; Indigenisation; Lamba tribe (Zambia); African Traditional Religion.

\section{Introduction}

It should be stated that humans, particularly in developing countries such as Zambia, engage in activities that are detrimental to the well-being of creation, in general, and humanity, in particular. In the name of economic development, investment and employment, a lot of harm has been caused to land, forests and water sources. Grim (ed. 2001:xv) rightly asks 'is the human a viable species on an endangered planet?'. From resource depletion and species extinction to pollution overload, this planet is in peril.

The copper mining industry in Zambia has a negative impact on biodiversity and nature. As a result of the mining and industrialised exploitation inter alia in the territory of Lamba, the Lamba people of the Copperbelt have increasingly noticed the extinction of species, loss of cultural heritage and the devaluation for nature.

Moltmann (1993) argues that:

[I]nterpreting the world as God's creation means precisely not viewing it as the world of human beings and taking possession of it accordingly. If the world is God's creation, then it remains his property and cannot be claimed by men and women. It can only be accepted as a loan and administered as a trust. (p. 30)

It is in view of this assertion that the copper mining industry's activities on the Copperbelt must be assessed critically in the light of Scripture. 
Human beings must desire to explore a better way to live with the rest of creation in harmony and interdependence. This follows Moltmann's (1993:4) assertion that a 'theological doctrine of creation in our own time is guided by the will to find a way into the community of creation'. If creation is a community of the humans and the non-humans, then care must be taken by the living in the way other members of the community are treated, especially by human beings in this case.

Schweiker (2004:37) aptly interprets the 'Golden Rule' of love, a norm for conduct and choice: 'Christians imitate Christ and so live in the new creation'. All actions and relations should be aimed at respect for life and to enhance it. Moltmann (2019:47) applies the Golden Rule in terms of Mathew 7:13, 'Everything that you want people to do you do that to them'. This reciprocity presupposes the equality of two sides involved. Moltmann (2018) therefore changes Luke 7:28 to read:

$[T]$ hou shalt love the Lord thy God with all thy heart, and with all thy soul, and with all thy strength, and with all thy mind; and thy neighbour [and the earth] as thyself. (p. 99)

Firstly, the situation in the Copperbelt in Zambia will be described. As a result of excessive mining, this once beautiful part of Africa where the Lamba people lived, is now an ecological wasteland. If eco-theology is needed anywhere, it is needed here too. The rest of the article discusses two traditions that inform the thinking relevant for the Copperbelt. In the second part of the article, the Christian tradition will be considered through an eco-theological lens. In the third and final part, the ecological merits of African traditional thought will be discussed. An indigenised, ecotheological re-assessment of these two traditions is needed, given the dire ecological situation of the Copperbelt in Zambia.

By means of a literature review, ethnographic information and governmental legislation, the article tries to illustrate how eco-theology could and should be indigenised in an African context using the Copperbelt in Zambia as a case study. This article wishes to contribute to the needed ecological renewal by reinterpreting two traditions that inform thinking on the Copperbelt: Christianity and ATR.

Both Christianity and the African traditional thought need to be transformed into eco-theological tools to address the ecological crisis which is very acute in the Copperbelt in Zambia. We will start with the Copperbelt as the case study.

\section{The Copperbelt as the case study The nature of the Lamba territory}

According to the Zambian law, all land is vested unequivocally in the President and is held by him in perpetuity for and on behalf of the people of Zambia (Zambian Government 1995:270). This implies that any officer or authority regulating the use of land acts on behalf of the President of the Republic of Zambia.

The Copperbelt province partly covers the territory of the Lamba people which stretches over an area of about 31328 square kilometres and is partly in the Congo but with a larger position in Zambia (Encyclopaedia Britannica 2013). Doke (1931:18) reports that the whole country is flat and slightly undulating with here and there isolated kopjes or low ranges of hill'. It used to be a beautiful countryside.

The land has trees but not thickly grown close to each other as in most places. It is covered by grassland with streams, mostly flowing towards the main rivers of Kafue on the South West and Luapula on the Northeast. The land is beautifully vegetative grown savannah type. Before deforestation took its toll on the land because of clearing for mining, settlements, farms and charcoal burning as a result of urbanisation, the land had all types of trees, grass and shrubs growing along streams, beside small hills and on dry land. The land's beauty is punctuated with streams, rivers, plains and hills, which appear at an average of $5-10 \mathrm{~km}$ stretch of land. The common trees are those which produce fibre such as the Julbernardia paniculata (muchesa) and Brachystegia boeltmill (umuombo) and the hardwoods Pterocarpus angolensis (mukwa). Fruit trees that served as additional nutrition for the local people include Pannari curafelifolia (Mbola), Uapaca kirkiana (sugar plum), Strychnos innocua (napal-orange) and many others. The forests on the Copperbelt provided the local and commercial traders with timber for construction and domestic use such as furniture, tool handles and weapons. Nowadays, most of these trees can no longer be found. ${ }^{1}$ The Copperbelt has become a barren wasteland.

When God-given vegetation is depleted in an area, particularly trees, the risk of desertification, reduced rainfall and increased windstorms become unavoidable. The Copperbelt has not been spared these resultant phenomena. Bush fires usually accidentally started by various activities ravage much of the grass vegetation. Tall trees, which provided much cover when left to overgrow so much that the grass grows in patches to allow fire control, have been cut off for various purposes. It, therefore, follows that insects, small animals, bird nests, crawling animals like snakes, snails and turtles perish or are depleted through fierce bush fires. This is because of settlements of the mining communities whose population has been rising from the inception of the copper mines.

Rivers such as the Kafue which passes through the Copperbelt province is the longest river in Zambia and has very few water species left because of pollution by heavy metals from the mining industry. Michael Cromartie (ed. 1995) maintains that 'human beings can disrupt natural balance with speed or intensity or scope that nature cannot accommodate' (p. 6). This is being witnessed in the 1.See https://allafrica.com/stories/201203240018.html. 
Copperbelt province of Zambia where the human species are on a rampage to degrade nature beyond the supporting capacities of the ecosystem.

Most developmental strategies, particularly by the copper mining industry, have been anthropogenic in nature, with no concern for other species than the development of human beings. Humans used the environment primarily for their own benefit. The resultant effects of such development have been soil erosion, soil alkalinity, soil impoverishment, lowered water table in rivers, streams and lakes; unnecessary floods in rivers with the slightest rainfall because the bare land terrain is unable to contain the water. The rate at which the degradation of nature is taking place in the absence of meaningful mitigation projects makes it difficult for the Lamba land to be reconstructed within a memorable time, not at least for generations to come. The suggestion that '...a natural system [can] reconstitute itself through stages of its primary or secondary succession and success...' (Goodman \& Edwards 1965:4), does not seem to satisfy. More drastic measures are needed.

\section{Impact of mining activities on nature and the environment}

Nowadays, mining is being regulated better. The latest law on mines and the processing of minerals in Zambia was enacted in 2008, when in fact mines had existed in the country for close to a century (Zambian Government 2008). In the new law, ecology and the environment are taken into consideration. However, a lot was left to be desired in terms of environmental management and mining rights before the current law.

Even now, the local communities in rural Zambia and townships are not aware of the negative impact of their own small-scale mining activities. For the majority, mine refers to large-scale copper or mineral extraction activity with an employment capacity for many people. Therefore, when it comes to environmental management and awareness, the blame is only aimed at large-scale mining companies; whilst small-scale mining activities equally contribute to the degradation of the environments and various levels of air and water pollution as well.

Zambia suffers so much damage to its land terrain by various types of small mining activities such as those who quarry for sand, building stones and gravel. Besides copper mining in Zambia, individuals engage in the extraction of the above mentioned (sand, stone and gravel) for constructions at an alarming rate, particularly in and around towns and cities. Rainy season flooding is partly caused by these kinds of mining activities, and very little attention is paid to this destructive industry in terms of regulating and sensitisation. People need to see nature in a different way. The refocusing of Christian and African traditional ways of thinking that is proposed in this article is needed desperately.
There has been many damage caused to land, the humans, non-humans and ecosystems in general wherever the mining industry - both large scale and small-scale - has been carrying out activities such as exploration, mine development, mineral extraction, processing and transportation. The following are some of the effects:

\section{- Air Pollution}

The surrounding features in an environment such as vegetation and air itself are heavily polluted by dust which comes from clearing sites for mines, mineral extraction particularly at open pits and emissions from the processing plants, such as the concentrator and smelting workshops. In and around the Copperbelt mining towns, dust particles are visible and can be removed by bare hands-on tree leaves, branches and shrubs. Emissions affect people, particularly in Mufulira. Respiratory difficulties are experienced by people who live in and around the smelting plants. Emissions from this part of the world add to ecological problems. Every day people experience the detrimental effects of mining in their own lives, in their own lungs. Something needs to be done.

- Water pollution

Water is one of the most easily polluted sources of livelihood for all creatures. The tailings dump system cannot work without large quantities of water. Whatever is pumped to the dams goes in liquid form, meaning that the end disposal is into streams, rivers, lakes and oceans. Underground water is equally polluted right from the processing plants to the dams. The case in point is one tailing dump dam \#15A outside the mining town of Kitwe, which by 2013, had an accumulated total dump of 138432881 tonnes of water, dust, mineral solutions and chemicals (Kapasha 2013, Interview on 29 November 2013, by L. Chibuye). This is an enormous, unimaginable amount of polluted water. Water carrying varying percentages of effluents are spilt into the rivers and the environment. Water is also polluted by waste ore, which does not include the overburdened earth and rock that are removed in order to reach the ore underground. This valuable resource, the world over and especially in Africa, is going to waste through mining. The very source of life is being destroyed.

- Alteration to landscape

Land becomes the first 'victim' in all mining activities. The mineral exploration stage may not seem to be involving much of land deformation or removal. However, when excavation, drilling and sinking of shafts are carried out, a lot of damage is done to land and vegetation. Heavy earthmoving machines are used at a very high rate. Both where the overburden is taken from and where it is heaped causes landscape alteration. This beautiful land, which had all types of trees, grass and shrubs growing along streams, beside small hills and on dry land, is no more. The Copperbelt used to be a gem in the heart of Africa, but now it is a barren wasteland. If an ecological revival is necessary anywhere, then it is here in this polluted, misshapen part of the countryside.

The global concern on global warming which has equally devastating effects on creation should not be underplayed by any individual, organisation or government. The Earth 
community is so interdependent that a problem in one part of the Earth directly or indirectly in a foreseeable future affects all creation, particularly on Earth. Vaughan-Lee (2013), says:

[S]oil comes first. It represents nature and sustains the entire world. Everything comes from the soil. Food which sustains life comes soil...for soil is a metaphor for the entire natural system. (p. 130)

Despite the emphasis on the soil in the above-quoted statement, it is imperative to note that soil is the foundation of the Earth community. That is to say, the web of life on Earth has its basis on the soil. The Earth Charter (2000) ${ }^{2}$ defines this predicament and challenge correctly:

We stand at a critical moment in Earth's history, a time when humanity must choose its future. As the world becomes increasingly interdependent and fragile, the future at once holds great peril and great promise. To move forward we must recognize that in the midst of a magnificent diversity of cultures and life forms we are one human family and one Earth community with a common destiny. We must join together to bring forth a sustainable global society founded on respect for nature, universal human rights, economic justice, and a culture of peace. Towards this end, it is imperative that we, the peoples of Earth, declare our responsibility to one another, to the greater community of life, and to future generations. (p. 1)

The irresponsible human activities have not spared water, which interrelates members of the Earth community in many ways. Earth is the only known planet in the solar system on which water occurs and, therefore, probably the only planet where life can develop and flourish as we know it. Water, therefore, is always in interaction with all non-human and human lives. The activities of human beings such as mining carried out inappropriately, polluting water and causing changes in the balance of natural water. Land, air and water are being destroyed. Something needs to be done.

The Lamba people used to live in a beautiful savannah of Africa. Over a century of mining, large-scale and small-scale, has transformed its land into an ecological disaster. The air is dirty, the water is polluted and the landscape has been destroyed. It is urgent that both Christianity and the African traditional thought are transformed into eco-theological tools to address the ecological crisis which is very acute in the Copperbelt in Zambia.

\section{The eco-theological potential of Christianity}

Human influence on the Earth system has been so profound that a new geological epoch has been suggested: the Anthropocene (cf. Pope 2016). It is undeniable that humanity has greatly benefited from the technocratic and technoscience

\footnotetext{
2.The Earth Charter was created by the independent Earth Charter Commission, which was convened as a follow-up to the 1992 Earth Summit in order to produce a global consensus statement consensus statement of values and principles for a sustainable future. The document was developed over nearly a decade through an extensive process of international consultation, to which over 5000 people contributed. The Charter has been formally endorsed by thousands of organisations, including United Nations Educational, Scientific and Cultural Organization (UNESCO) and the International Union for Conservation of Nature (IUCN).
}

paradigm, that is where and when technoscience is properly used and well-directed, human life and the well-being of the web of life, in general, have greatly improved.

Humanity has advanced greatly in the means of transportation, electricity, chemical industries, machinery and biotechnology. This is because 'science and technology are wonderful products of God-given human creativity' (Francis 2015:59). Human beings today can travel long distances within a short period of time; communication is carried out by the press of a device and business can be concluded within minutes, if not seconds. As a result of advanced technology, individuals and communities can produce more goods and services within a short time and have them distributed accordingly.

Medicine, engineering, communication and transportation are areas in which science and technology have improved the welfare of humanity. However, we need to ask ourselves whether the advancement in science and technology has matched with human responsibility and ethical consciousness.

Human beings' existence depends on the well-being of all creation. Pope Francis appropriately states that 'the loss of forests and woodlands entails the loss of species which may constitute extremely important resources in the future, not only food but also for curing disease and other uses' (Francis 2015:23). The case in point is the misuse of soil by the use of heavy industrial machinery and chemicals in agriculturerelated activities, mining and construction. A lot has been said and heard regarding happenings in communities, yet little effort, if any, is being made to curb the deforestations, land degradation and land pollution by industries, governments and communities in general.

Mining on the Copperbelt in Zambia started around the same time that Christianity arrived in the area. Both were introduced by people from the West. Christianity has often been linked with the destruction of our environment, but Christianity also has the potential to be an eco-theological tool to do good.

The dominium command to 'subdue the earth and rule it...' (Gn 1:28) is often interpreted as a basis for ecological destruction. Our contention is that this is a misinterpretation of the passage and many others. These passages are not responsible for the indiscriminate use of land and natural resources by humans. Buitendag (2019:315) argues in a recent article with the compelling title, 'You must love the earth as yourself', that the ecological crisis is not the result of obedience to the dominion command but the history of disobedience to Scripture.

The focus of Christianity should not be on humanity alone but on God's creation in its entirety. Mining may benefit humans, but if it destroys nature it is wrong. Nature cannot be claimed by people.

Human beings must desire to explore a better way to live with the rest of creation in harmony and interdependence. 
This follows Moltmann's (1993:4) assertion that a 'theological doctrine of creation in our own time is guided by the will to find a way into the community of creation'. If creation is a community of humans and non-humans, then care must be taken by living in the way other members of the community are treated, especially by human beings in this case. Humans must take care of the land, not pollute and destroy it.

Schweiker (2004:37) aptly interprets the 'Golden Rule' of love a norm for conduct and choice: 'Christians imitate Christ and so live in the new creation'. All actions and relations should be aimed at respect for life and to enhance it. Moltmann (2019:47) applies the Golden Rule in terms of Mathew 7:13, 'Everything that you want people to do you - do that to them'. This reciprocity presupposes the equality of two sides involved.

Moltmann's colleague Pannenberg (1994) makes a similar point with respect to the much debated and misinterpreted dominium command:

[T]he criticism of biblical anthropology that blames the giving of dominion in Genesis 1:28 for the unrestricted exploitation of nature by modern technology and industrial society, and for the resultant ecological crisis, must be rejected as without merit. (p. 204)

Christianity is not the cause of ecological destruction, although it may have arrived at the Copperbelt in Zambia around the same time. Pannenberg (1994) points out a common fallacy that is used in this respect:

$[C]$ ontemporary secularism, while boasting of its emancipation from religious ties, at the same time places responsibility for the consequences of its absolutizing of the striving for possessions on the religious origins from which it has broken free. (p. 204)

Secularism cannot claim the benefits of engineering for itself whilst simultaneously blaming Christianity for the detrimental effects of engineering. Christianity as such is not responsible for the exploitation that happened in the Zambian Copperbelt in the past century. The dominium command from Genesis allows people to work in the world, but it remains God's world. As Pannenberg (1994) continues:

This dominion, then, excludes control or exploitation. It is like the work of a gardener, as in the second creation story (Gen 2:15). Because the world of nature is still God's, in spite of being handed over to us to rule. (p. 205)

Just like a gardener is obviously not invited to destroy the garden of his employer, so Christians are asked to take good care of God's creation. What happened on the Copperbelt is not Christian.

The dominion command in Genesis 1: 26-28 spells out responsibility on the part of human beings. This is qualified in the second creation story of Genesis 2:15, where humans are to cultivate and keep the 'garden', in this case the creation of God.

The first creation story places humans at the end of creation sequence, an indication that the Creator had to prepare for the existence of humans, not indicating any supremacy at all, but the role of stewardship. Humans have been hosted by Earth and all its components; the fauna and the flora; humans and non-humans, big and small and the rest.

The stewardship mandate given to humanity in the second creation story along with the dominion command of the first creation story should be the point of departure for human intensiveness in putting away practices and activities that violate our ethical conduct in the interdependence relationship. The notion of exploitative anthropocentrism must be discarded.

The argument is that economic prospects and developmental projects often tend to ignore the existence and sustainability of life in diversity and the natural world. Leonardo Boff in his book, Cry of the earth, Cry of the people, rightly observes that 'when development and environment conservation are in tension, development is usually chosen, and the cost paid is environmental deterioration' (Boff 1997:5). In the global village of information technology, trade, and the rest of the shared interests in the Earth community, any form of anthropocentrism by any human community possesses a danger to the entire web of life.

One of the most important aspect of human life to be addressed is the attitude towards the environment. This is the disposition or state of mind and perception of creation and the non-human in the natural world. In most cases, humans talk about the environment in relation to their interests, not to the benefit of the non-human. Humans must desire to explore a better way to live with the rest of creation in harmony and interdependence, or as Moltmann (1993:3) states, 'Nature must no longer be viewed as unclaimed property'.

Failure of human beings to regard creation as a community to which they (humans) belong is a proclamation of doom for the entire creation. The quest for sustainability, therefore, entitles the ability of natural resources to provide for both the present and future generations.

From a Christian perspective, humans are a part of nature, merely asked to perform certain duties within it (Gn 2:15). We need nature, but nature does not need us (Moltmann 2019:16). A human is rather a 'cosmic image', seeing that the Gestalt of humans is embedded in nature and society (Buitendag 2019:312). We depend upon nature, and nature depends upon God. By exploiting nature, human beings have overstepped their creational boundaries by far.

If God saw that all that was created was very good (Gn 1:31), then we begin to raise questions of how climate has become bad, and very bad indeed, why we have specialised depletion, why we have deforestations and land degradation in most communities of Earth, particularly in the so-called developing nations, and how water bodies are polluted and their aqua life species depleted and deformed. 
Do we then say that Earth is looked at as invaluable, having hosted all those people and tribes for generations? The Earth cannot end up being looked down upon as worthless and without purpose. We cannot deny, although that 'the intrinsic worth of earth and mutual custodianship between humans and earth are not respected' (Habel 2002:58-59). Humans have a responsibility as caregivers and tenders of the Earth.

How much responsibility does humanity have for the preservation of future generations in the use of science and technology? If countries continue to test for nuclear bombs, where they have been used, they have had devastating effects on both the present and future states of the environment. Responsible humanity must not just think of itself during a particular generation but should think of the future of all creation including humanity itself. Schweiker (2004:xiv) is therefore correct in seeking an imperative of responsibility in order to provide orientation for responses to overhumanisation. 'This age is endangered by the threat of over humanization in such a way that a deep commitment to the integrity of life is required' (Schweiker 2004:xix). Such a commitment is deeply Christian, and it matches African traditional thought as well.

\section{The eco-theological potential of African traditional thought}

Like many African people, the Lamba people of Zambia's Copperbelt in their traditional ways of thinking refer to God as the Creator of people and all that are around them. In fact, God is conceived and understood although not so clearly, with reference to the many things God has created. Mbiti (1969) says that, 'African ontology is firmly anthropocentric, and this makes man look at God and nature from the point of his relationship with them' (p. 48). The focus is on human beings, but they are always seen as being in relationship with everything around them. Humans are perceived as just a small part of the wealth of natural and spiritual beings. Like the Kenyan Noble prize winner Maathai said, in the African tradition (cited in Orobator 2018):

$[N]$ ature is not something set apart, with or against which we react. It's not a place we fear as something within which we might lose humanity or, conversely, a place where we might gain perspective and simplicity away from the corruption and treachery of the court or the city. It is, instead, something within which human beings are enfolded. (p. 118)

Humans and the nature around them are intricately related. Through nature, people in Africa are related to the spirit world.

For the Lamba people, therefore, clearing forests, flattening hills and polluting water streams and rivers for the purpose of copper mining are alienating them from the Creator. They believe that ancestral spirits and many other spirits related to their welfare live amongst the forests along streams, in hills and in mountains. These are dwelling places for spiritual powers responsible for their welfare as individuals, as families and as communities. In view of the destruction caused to nature, traditional communities of the Copperbelt have been cut off from their relationship with the conceived deity and their spiritual world.

Moltmann (2019:43) shares a story of a South African of his telling him that his father has asked forgiveness from the spirit of the tree, before chopping it down for a canoe. Then a Christian missionary came and said it is idolatry to pray to the spirit of a tree. Just subdue the earth and chop down the tree. Yet now, we realise that the father made an important point. Trees are vital to Earth's organism. Like Maathai says, 'If we love the environment, we must identify with the tree that is cut down' (quoted in Orobator 2018:111). That is the true African way of thinking.

African mythologies serve as a source of wisdom in caring for nature and the environment. If 'myths are sacred narratives explaining how the world and humankind came to be in their present form and are therefore closely linked to religion' (eds. Deane-Drummond \& Bedford-Strohm 2011:132), then we realise that a great deal must be learned from African mythologies.

In almost all ATRs, forests, land, water body's plains, hills and mountains are regarded as sacred for as long as human communities depend on them for their livelihood (cf. Mbiti 1969:24 et passim). The soil provides food, plants for relish; the water is used in all aspects of life from birth to death. A newly born baby is first washed with water, and a dead person's body is ceremonially washed with water before burial. In between birth and death, water remains a vital element in life. Posey (2001) applies this to the Kagora Shona people of Zimbabwe and to many other faiths:

Wells and springs are also frequently considered as holy and the areas around them specially protected from disturbance. Springs, for example, are the 'soul of the Hopi people, representing their very identity'. Oases, too, can be sacred places for people like the Masai and Fulani pastoralists, whose lives during severe droughts literally depend upon these protected areas. (p. 11)

Forests, grass and all that consists in the environment provide for human needs in various ways. The Lala tribe of central Zambia refers to water, for instance, as mother, which cannot contaminate a person. These mythological benefits and sayings can serve as a source for practical means of preserving human interdependence on the rest of the creation.

Humanity needs to do away with the arrogance that puts itself at the centre of everything, the failure to see the Earth as the object of God's loving care and participation in a culture where human power, dominance and greed denudes the Earth. The Paris Protocol of 2015 resolution ${ }^{3}$ should be taken seriously by the powers that be, whether in developed or non-developed nations. The effect of stubbornness to 3.For a proper exposition and analysis of the Paris Agreement, see Dröge (2016). 
withdraw from such innervation affects the entire creation negatively.

Those in industrialised communities such as where emissions and pollutants are produced must be able to abide by the international, regional and national regulations. Communities that largely depend on nature such as the agriculture communities that clear large portions of land for farming activities must practice crop rotation to avoid further clearing of land. Wood fuel and other use of forests, which are not sustainable, must be mitigated by planting tree species that can grow and regenerate within a short period.

It is important to educate communities on the value of preserving the natural wild. Subjects on the environment and the value of other creatures besides humans must be adopted to contextual needs of each community or country. The mindset of individuals and communities that has been referred to above is very pivotal, but it takes intensive regulations and education facilitation by authorities. Both Christianity and the African traditional thought need to be transformed into eco-theological tools to address the ecological crisis, which is very acute in the Copperbelt in Zambia as we have seen.

Examples of the kind of interventions that are needed include the planting of trees, harvesting of water from drainages, careful management of litter both in industry and in residential communities, use of renewable energy sources, reduction in carbon emissions, stopping deforestation for various reasons such as agriculture activities, settlements and domestic use for fuel. An excellent example of this sort of intervention in Africa is the work Professor M. L. Daneel did in Zimbabwe with his 'war of trees' campaign offering an ecumenical platform to unite churches in order to launch environmental reform.

The Association of African Earthkeeping Churches (AAEC) was established in 1991 and the initial steps were taken towards a new environmental ethic and practical objectives of the AAEC constitution entailed: afforestation, wildlife conservation and protection of water resources (Daneel 1996:573). ${ }^{4}$

The ecological crisis worldwide has given rise to the call for everyone to work together to start caring about our natural environment. In theology, the response to this call received the name eco-theology. As we have seen here, eco-theology can be found both in Christianity and in African traditional thought. These resources are desperately needed to deal with the acute ecological crisis in the Copperbelt in Zambia.

4.The church could act as a vehicle to organisations and conferences on climate change such as Conference of Parties, and United Nations Framework Convention on Climate change. More funding is needed for the church-based programmes such as Southern African Faith communities Environment Institution, Action by Churches as Southern African Faith communities Environment Institution, Action by Churches Together and Fellowship of Churches in Southern Africa to carry out educational programmes in their member denominations and the communities. The mos appealing contribution from Africa in this regard is the Accra Confession (2004). 'It is based on the theological conviction that the economic and environmental injustices of today's global economy require the reformed family to respond as matter of faith in the gospel of Jesus Christ' (WCRC 2004:1). It is a calling upon Reformed Christians from all over the world to 'engage injustices in the world as an integral part of their churches' witness and mission' (WCRC 2004:1).

\section{Conclusion}

When God had completed creation, he saw that everything he had created was very good (Gn 1:31). This implies that everything from light, the sky, water, land, grass, fruit trees, sun and stars, days and years, fish, sea monsters and birds, crawly creatures and wild animals and men and women. If humanity is to appreciate that all that was created was to the Glory of God, then the biblical command to keep, tend and look after creation must be adhered to. If anyone fails to do what God requires of him/her, he/she disobeys God, in this in looking after what is entrusted to humanity, that is creation.

Obedience to God's command to tend creation is a quest for continued creation by humans, so that value is added to what is already in existence. This is embodied in making the place we live in more beautiful, appealing and peaceful. Fruitfulness with sustainability becomes core values for interdependence and mutual custodianship of the Earth community.

The mandate to preserve creation is divine because it comes from the Creator (Gn 2:15). All faiths must be realistic of the vocation to 'preach' the message of reconciliation with the rest of creation. Governments, transnational and multinational organisations and all human communities are called upon to rise to the challenge of ecological crises because of the mismanagement of creation. It is a collective responsibility because it affects all, regardless of the location.

The supernatural belief of the Lamba people is no longer embodied in this creation, and it is not too late for the people to form any indigenous environmental protection movement to protect the sacredness of mother Earth from further contamination and exploitation by strengthening, maintaining and respecting the traditional teachings and the cultural laws (ed. Grim 2001:509).

Land is a place of mystery, silence and meeting. 'We have to learn from the Aboriginal experience as we develop a contextualized spirituality of creation for the Anthropocene' (Pope 2016:99).

In this article, we have shown how eco-theology could and should be indigenised in an African context using the Copperbelt in Zambia as a case study. We saw that, as a result of excessive mining, the once beautiful Copperbelt in Zambia, where the Lamba people live, is now an ecological wasteland. If eco-theology is needed anywhere, then here. We discussed two traditions that inform the thinking relevant for the Copperbelt: Christianity and African traditional thought. Both ways of thinking have been considered through an eco-theological lens. An indigenised, eco-theological re-assessment of these two traditions has been provided. This is needed badly considering the dire ecological situation of the Copperbelt in Zambia. 
Thomas Berry (1914-2009) argues that we must listen to the stories of indigenous people of the land to regain nature's intrinsic nature. Berry prefers to replace the terminal Cenozoic era to an emerging Ecozoic period, which is defined as 'that period when humans would be present to the Earth in a mutually enhancing manner' (Berry 2009:loc. 1609). The Ecozoic era is the emerging period in which humans would recover their creative orientation to Earth and marking the end of a geological era in which thousands of species have become extinct (Tucker \& Grim 2014):

The unity of the universe can be observed in the vast array of rituals carried out by diverse indigenous peoples around the planet, as well as by the agricultural and literate societies, especially in their founding stages. (p. 56)

\section{Acknowledgements}

The authors thank the people who assisted them in the proofreading and editing of this research article.

\section{Competing interests}

The authors declare that they have no financial or personal relationships that may have inappropriately influenced them in writing this research article.

\section{Authors' contributions}

L.C. and J.B. contributed equally, but the research is based on the first author's dissertation.

\section{Ethical considerations}

This article followed all ethical standards for research without direct contact with human or animal subjects.

\section{Funding information}

This research received no specific grant from any funding agency in the public, commercial or not-for-profit sectors.

\section{Data availability statement}

Data sharing is not applicable to this article as no new data were created or analysed in this study.

\section{Disclaimer}

The views and opinions expressed in this article are those of the authors and do not necessarily reflect the official policy or position of any affiliated agency of the authors.

\section{References}

Berry, T., 2009, The sacred universe: Earth, spirituality, and religion in the twenty-first century, Columbia University Press, New York, NY.

Boff, L., 1997, Cry of the Earth, cry of the poor, Orbis Books, New York, NY.

Buitendag, J., 2019, 'Jy moet die aarde liefhê soos jouself', LitNet (Akademies) 16(3), 305-320, viewed 20 April 2020, from https://www.litnet.co.za/wp-content/ uploads/2019/12/LitNet_Akademies_16-3_Buitendag_305-320.pdf.

Chibuye, L., 2016,'An eco-theological assessment for the sustainability of creation: The case of the Copperbelt province in Zambia', PhD dissertation, Faculty of Theology, University of Pretoria.

Cromartie, M. (ed.), 1995, Creation at risk? Religion, science, and environmentalism, William B. Eerdmans Publishing, Cambridge.

Daneel, M.L., 1996, 'African independent churches face the challenge of environmental ethics', in R.S. Gottlieb (ed.), This sacred earth, pp. 572-585, Routledge, New York, NY.

Deane-Drummond, C. \& Bedford-Strohm, H. (eds.), Religion and ecology in the public sphere, T \& T Clark, New York, NY.

Doke, C., 1931, The Lambas of Northern Rhodesia, George G. Harrap and Co., London.

Dröge, S., 2016, The Paris Agreement 2015: Turning point for the international climate regime, SWP Research Paper, German Institute for International and Security Affairs, Stiftung Wissenschaft und Politik, Berlin.

Earth Charter International (ECI), 2000, viewed 20 April 2020, from https:// earthcharter.org/wp-content/uploads/2020/03/echarter_english.pdf?x46713.

Francis, P., 2015, LAUDATO SI': Encyclical Letter of the Holy Father Francis on care for our common home, Pauline Publications Africa, Nairobi.

Goodman, G. \& Edwards, A., 1965, Ecology and the industrial society, Blackwell Publications, London.

Grim, J.A. (ed.), 2001, Indigenous traditions and ecology: The interbeing of cosmology and community, Publications of the Center for the Study of World Religions, Harvard Divinity School, Harvard University Press, Cambridge, MA.

Habel, N., 2002, Readings from the perspective of the Earth, Sheffield Academic Press, Sheffield.

Mbiti, J., 1969, African religions and philosophy, Heinemann Educational Books Ltd., London.

Moltmann, J., 1993, God in creation, SCM Press, Minneapolis, MN.

Moltmann, J., 2018, Christliche Erneuerungen in schwierigen Zeiten, Claudeus Verlag, München.

Moltmann, J., 2019, The spirit of hope: Theology for a world in peril, John Knox Press, Westminster.

Orobator, A.E., 2018, Religion and faith in Africa: Confessions of an Animist, Orbis Books, Maryknoll, New York, NY.

Pannenberg, W., 1994, Systematic theology, vol. 2, William B. Eerdmans, Grand Rapids, MI.

Pope, M., 2016, 'Rediscovering a spirituality of creation for the Anthropocene', in G. Buxton \& N. Habel (eds.), The nature of things, pp. 92-100, Pickwick Publications, Eugene, OR.

Posey, D.A., 2001, 'Intellectual property rights and the sacred balance: Some spiritual consequences from the commercialization of traditional resources', in J.A. Grim (ed.), Indigenous Traditions and Ecology, pp. 3-23, Center for the Study of World Religions, Harvard Divinity School, Cambridge, MA.
Relican

Schweiker, W., 2004, The theological ethics and global dynamics: In the time of many worlds, Blackwell Publishing, Oxford.

The Editors of Encyclopaedia Britannica, 2013, 'Copperbelt', Encyclopaedia Britannica, viewed 03 March 2020, from https://www.britannica.com/place/Copperbeltprovince-Zambia.

Tucker, M.E. \& Grim, J., 2014, Thomas Berry: Selected writings on the Earth community, Orbis Books, New York, NY.

Vaughan-Lee, L. (ed.), 2013, Spiritual ecology - The cry of the Earth, The Golden Sufi Centre, Point Reyes.

World Communion of Reformed Churches (WCRC), 2004, The Accra Confession 24 March 2020, from http://wcrc.ch/wp-content/uploads/2015/04/TheAccra Confession-English.pdf.

Zambian Government, 1995, Lands Act (No. 29 of 1995), Lusaka.

Zambian Government, 2008, Mines and Minerals Development Act (No.7 of 2008), FAOLEX, Lusaka. 